\title{
The in vitro sustained release profile and antitumor effect of etoposide-layered double hydroxide nanohybrids
}

This article was published in the following Dove Press journal:

International Journal of Nanomedicine

23 May 2013

Number of times this article has been viewed

\author{
Lili Qin' \\ Mei Wang ${ }^{2}$ \\ Rongrong Zhu ${ }^{3}$ \\ Songhui You' \\ Ping Zhou' \\ Shilong Wang ${ }^{3}$ \\ 'Department of Physical Education, \\ Tongji University, Shanghai, People's \\ Republic of China; ${ }^{2}$ Department of \\ Chemistry, Tongji University, Shanghai, \\ People's Republic of China; ${ }^{3}$ School \\ of Life Science and Technology, Tongji \\ University, Shanghai, People's Republic \\ of China
}

Correspondence: Shilong Wang School of Life Science and Technology, Tongji University, 1239 Siping Road, Shanghai 200092, People's Republic of China

Tel +862165982595

Fax +862165982286

Email wsı@tongji.edu.cn
Abstract: Magnesium-aluminum layered double hydroxides intercalated with antitumor drug etoposide (VP16) were prepared for the first time using a two-step procedure. The X-ray powder diffraction data suggested the intercalation of VP16 into layers with the increased basal spacing from $0.84-1.18 \mathrm{~nm}$ was successful. Then, it was characterized by X-ray powder diffraction, Fourier transform infrared spectroscopy, thermogravimetry and differential thermal analysis, and transmission electron microscopy. The prepared nanoparticles, VP16-LDH, showed an average diameter of $62.5 \mathrm{~nm}$ with a zeta potential of $20.5 \mathrm{mV}$. Evaluation of the buffering effect of VP16-LDH indicated that the nanohybrids were ideal for administration of the drugs that treat human stomach irritation. The loading amount of intercalated VP16 was $21.94 \%$ and possessed a profile of sustained release. The mechanism of VP16-LDH release in the phosphate buffered saline solution at $\mathrm{pH} 7.4$ is likely controlled by the diffusion of VP16 anions from inside to the surface of LDH particles. The in vitro cytotoxicity and antitumor assays indicated that VP16-LDH hybrids were less toxic to GES-1 cells while exhibiting better antitumor efficacy on MKN45 and SGC-7901 cells. These results imply that VP16-LDH is a potential antitumor drug for a broad range of gastric cancer therapeutic applications.

Keywords: layered double hydroxides, etoposide, drug delivery, antitumor effect, sustained release

\section{Introduction}

Etoposide (VP16) (Figure 1) is a semisynthetic derivative of podophyllotoxin, which acts by inhibition of one of the most abundant nuclear proteins, deoxyribonucleic acid (DNA) topoisomerase 2. Etoposide is cell cycle-specific and leads to an accumulation of cells in G2/M. ${ }^{1}$ Thus, it has a significant effect on a large range of carcinomas, particularly gastric cancer cells, small cell lung carcinoma, germ cell tumors, hematologic malignancies, and childhood malignancies. However, the inhibition of enzymes can only be saturated at high drug concentrations with prolonged exposure, which would lead to greater cytotoxicity. ${ }^{2-5}$ Moreover, deficiencies such as poor water solubility, metabolic inactivation, drug resistance, myelosuppression, and poor bioavailability have limited their scopes of applications. ${ }^{6-8}$ As a result, a drug delivery system may represent an attractive prospect for overcoming these pharmaceutical limitations and improving their clinical application.

Layered double hydroxides (LDHs) are a family of anionic clay materials, exemplified by the natural mineral hydrotalcite $\left[\mathrm{Mg}_{6} \mathrm{Al}_{2}(\mathrm{OH})_{16} \mathrm{CO}_{3} \cdot 4 \mathrm{H}_{2} \mathrm{O}\right]$. All LDH minerals found in nature and synthesized in the laboratory have a structure similar to that of hydrotalcite or its hexagonal analog, manasseite. The majority adhere to the 


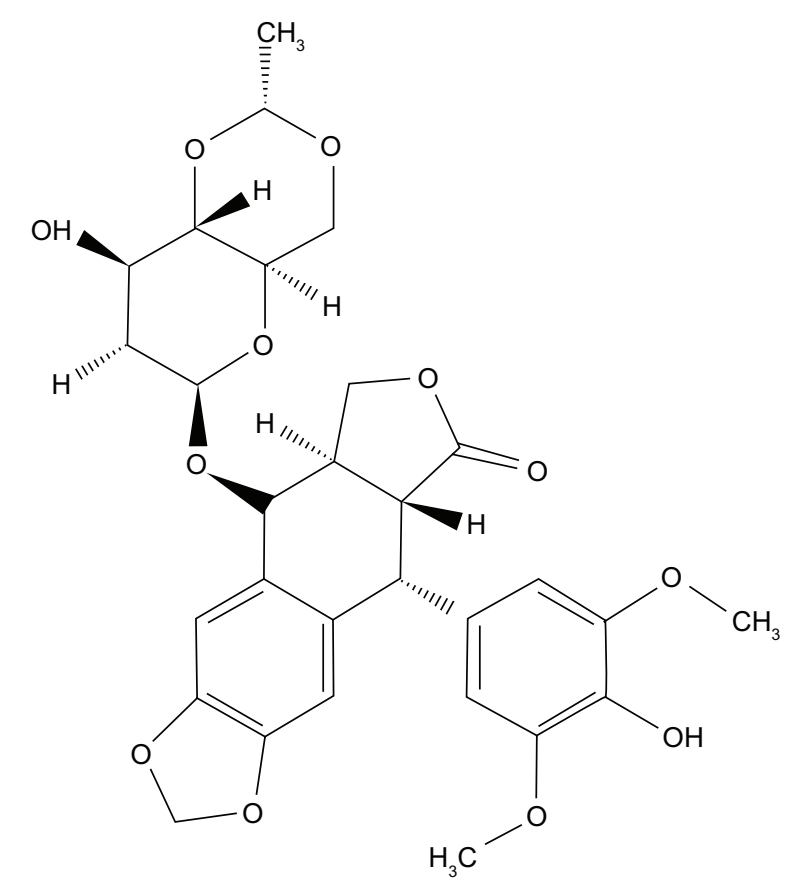

Figure I Molecular formula of etoposide (VPI6).

Abbreviation: VPI6, etoposide.

general formula $\left[\mathrm{M}_{1-\mathrm{x}}{ }^{2+} \mathrm{M}_{\mathrm{x}}{ }^{3+}(\mathrm{OH})_{2}\right]\left[\mathrm{A}_{\mathrm{x} / \mathrm{n}}\right] \mathrm{mH}_{2} \mathrm{O}$, where $\mathrm{M}^{2+}$ and $\mathrm{M}^{3+}$ represent divalent and trivalent cations octahedrally coordinated to hydroxyl ions, $\mathrm{A}^{\mathrm{n}-}$ is the interlayer organic or inorganic anion with negative charge, $M$ is the number of interlayer water molecules, and $\mathrm{x}=\mathrm{M}^{3+} /\left(\mathrm{M}^{2+}+\mathrm{M}^{3+}\right)$ stands for the layer charge density of $\mathrm{LDH}^{9}{ }^{9,10}$ In recent years, LDHs have been found to have promising use in biomedicine. Their low cost, good biocompatibility, low toxicity to mammalian cells, controlled-release system, and ability to provide full protection for loaded drugs make them suitable candidates for drug delivery systems. ${ }^{11,12}$ Many LDH compounds intercalated with beneficial organic anions, such as deoxyribonucleic acid DNA, ${ }^{13-16}$ amino acids, ${ }^{17-22}$ anionic polymers, ${ }^{23}$ pesticides, ${ }^{24,25}$ and drugs, ${ }^{26-30}$ have been prepared successfully. Special interests have focused on exploring the possibilities of using LDH drug delivery systems to deliver antiinflammatory drugs, ${ }^{31}$ anticoagulants like heparin, ${ }^{32}$ or anticancer drugs. ${ }^{33,34}$ These studies involve some basic issues, including the intercalation (loading) of drugs or biomolecules into the LDH interlayer, the release behaviors of drugs or biomolecules from the LDH interlayer under different physiological conditions, the toxicity of LDH materials to cells, the cellular uptake of LDH nanoparticles, and cellular drug delivery tests. Furthermore, this drug delivery system can be modified to target specific cells or organs, thereby expanding its application range.

The aim of this paper was to intercalate the antitumor drug VP16 into the LDH interlayer and characterize the resultant nanohybrids with a set of tests. The buffer effect and release behavior were also evaluated. The in vitro cell cytotoxicity and antitumor assays showed VP16-LDH to be less toxic to GES-1 cells while providing better antitumor efficacy on MKN45 and SGC-7901 cells.

\section{Materials and methods Materials}

Etoposide was a kind gift from the University of Science and Technology of China. $\mathrm{Mg}\left(\mathrm{NO}_{3}\right)_{2} \cdot 6 \mathrm{H}_{2} \mathrm{O}, \mathrm{Al}\left(\mathrm{NO}_{3}\right)_{3} \cdot 9 \mathrm{H}_{2} \mathrm{O}$, and tyrosine (Tyr) were purchased from the China National Medicine Group, Shanghai Chemical Reagents Company (Shanghai, People's Republic of China), and were used without further purification. Roswell Park Memorial Institute-1640, fetal calf serum, penicillin $\mathrm{G}$, streptomycin, and trypsinase were obtained from Gibco-BRL (Life Technologies Corporation, Grand Island, NY, USA). Dimethyl sulfoxide and MTT [3-(4,5-dimethylthiazol2-yl)-2,5-diphenyltetrazolium bromide] were purchased from Sigma-Aldrich (St Louis, MO, USA). Deionized water was decarbonated by boiling before use in all applications.

\section{Preparation of nanohybrids}

The nanohybrids were prepared using a two-step procedure, which we described previously. ${ }^{28,34}$ First, Tyr-LDH was prepared via the coprecipitation method under a nitrogen $\left(\mathrm{N}_{2}\right)$ atmosphere, as is conventional to minimize or avoid contamination by atmospheric $\mathrm{CO}_{2} \cdot{ }^{35} \mathrm{~A}$ mixed solution of $1 \mathrm{M} \mathrm{Mg}\left(\mathrm{NO}_{3}\right)_{2} \cdot 6 \mathrm{H}_{2} \mathrm{O}$ and $\mathrm{Al}\left(\mathrm{NO}_{3}\right)_{3} \cdot 9 \mathrm{H}_{2} \mathrm{O}(\mathrm{Mg}$ : $\mathrm{Al}$ ratio of 3:1) was added dropwise to an aqueous solution of $1 \mathrm{M}$ Tyr while vigorously stirring under a nitrogen atmosphere at room temperature. The $\mathrm{pH}$ of the resultant suspension was then adjusted to $10.0 \pm 0.2$ by adding $1 \mathrm{M} \mathrm{NaOH}$ solution dropwise while vigorously stirring at $80^{\circ} \mathrm{C}$ for 5 hours in a nitrogenfilled environment. This resulted in the formation of Tyr-LDH precipitates, which were then harvested by filtering, vacuum dried overnight, and used for subsequent investigations.

Second, VP16-LDH nanohybrids were prepared via ion exchange. The freshly prepared Tyr-LDH suspension was added to a $0.1 \mathrm{M}$ VP16 solution ( $\mathrm{pH}$ previously adjusted to 12 using $\mathrm{NaOH}$ ). The mixture was magnetically stirred continuously under a nitrogen atmosphere at $80^{\circ} \mathrm{C}$ for 5 hours. The resultant slurry was then filtered, washed thoroughly with decarbonated water, and dried overnight. The product was denoted as VP16-LDH.

\section{Characterization}

X-ray powder diffraction (XRD) patterns were recorded on a Rigaku Miniflex Diffractometer (Rigaku Corporation, Tokyo, 
Japan) using CuKa radiation ( $\lambda=0.154060 \mathrm{~nm}, 40 \mathrm{kV}, 40 \mathrm{~mA}$, step of $0.0330^{\circ}$ ). The average particle size (z-average size) and size distribution were measured using photon correlation spectroscopy (LS230, Beckman Coulter Inc, Brea, CA, USA) at $25^{\circ} \mathrm{C}$ under a fixed angle of $90^{\circ}$ in disposable polystyrene cuvettes. The measurements were recorded using a He-Ne laser of $633 \mathrm{~nm}$. Zeta potential distribution of the nanoparticles was analyzed by Nano ZS (Malvern Instruments, Malvern, UK). Fourier transform infrared spectroscopy were obtained on a Bruker Vector 22 spectrophotometer in the range of $4000-500 \mathrm{~cm}^{-1}$ using the standard $\mathrm{KBr}$ disk method (sample/ $\mathrm{KBr}=1 / 100$ ) (Bruker AXS, Inc., Billerica, MA, USA). Thermogravimetry (TG) and differential thermal analysis (DTA) were carried out on a Perkin-Elmer Pyris 1 TG/DTA instrument with a heating rate of $10^{\circ} \mathrm{C} /$ minute in flowing air (PerkinElmer, Waltham, MA, USA). Transmission electron micrographs were taken using a JEOL 1230 transmission electron microscope (TEM) (JOEL, Tokyo, Japan). Ultraviolet-visible (UV-VIS) absorption spectra were measured on a Cary 50 spectrophotometer (Varian, VIC, Australia).

\section{Evaluation of the buffer effect}

The buffer effect of VP16-LDH was evaluated by monitoring the $\mathrm{pH}$ changes in each suspension with the addition of $1 \mathrm{M}$ $\mathrm{HCl}$ aqueous solution. A typical experiment was performed using a $100 \mathrm{mg}$ sample in $10 \mathrm{~mL}$ of deionized distilled water. The flask was stirred continuously at $37^{\circ} \mathrm{C}$. Aqueous $\mathrm{HCl}$ solution was subsequently added to each suspension until $\mathrm{pH}$ stabilized at an approximate value of 1 .

\section{In vitro VPI6 release test from VPI6-LDH}

To determine the amount of VP16 loaded into the LDH, a standard weight of the nanohybrids and $5 \mathrm{~mL}$ of $1 \mathrm{M} \mathrm{HCl}$ were placed in a $10 \mathrm{~mL}$ flask. The solution was stirred until LDH layers were completely dissolved and subsequently analyzed with a UV-VIS spectrophotometer against a series of standards prepared using the same method; the concentration of VP16 was determined by monitoring the absorbance at $285 \mathrm{~nm}$ and calculated according to an obtained standard curve of VP16 $(\mathrm{A}=0.0113 \mathrm{C}+0.0008, \mathrm{r}=0.9988)$. The drug loading was calculated as follows:

$$
\begin{aligned}
& \text { Drug loading (w/w) } \\
& =\frac{\text { Weight of VP16 in LDH }}{\text { Weight of LDH }} \times 100 \%
\end{aligned}
$$

The VP16 release test was performed in phosphate buffered saline solutions $(0.02 \mathrm{M})$ of $\mathrm{pH} 7.4$ and 4.6 containing $0.02 \mathrm{~g}$ of VP16-LDH while gently shaking at a constant temperature of $37^{\circ} \mathrm{C}$. Aliquots $(2 \mathrm{~mL})$ were withdrawn at desired time intervals and filtered through a $0.45 \mu \mathrm{m}$ syringe filter. The accumulated amount of VP16 released was determined by UV absorption at $285 \mathrm{~nm}$. Four dissolution-diffusion kinetic models were used to fit the in vitro VP16-LDH release profiles. ${ }^{36-40}$

The zero-order model:

$$
\mathrm{M}_{\mathrm{t}}-\mathrm{M}_{0}=\mathrm{kt}+\mathrm{a}
$$

The first-order model:

$$
\operatorname{Ln}\left(M_{t} / M_{0}\right)=-k t+a
$$

The parabolic diffusion model:

$$
\left.\left(1-\mathrm{M}_{\mathrm{t}} / \mathrm{M}_{0}\right) / \mathrm{t}\right)=\mathrm{kt}^{-0.5}+\mathrm{a}
$$

The modified Freundlich model:

$$
1-\mathrm{M}_{\mathrm{t}} / \mathrm{M}_{0}=\mathrm{kt}^{\mathrm{a}}
$$

The zero- and first-order models are normally used to describe dissolution phenomena. The parabolic diffusion model expresses the diffusion controlled-release process. The modified Freundlich model explains diffusion behavior via ion exchange. In these equations, $\mathrm{M}_{0}$ and $\mathrm{M}_{\mathrm{t}}$ are the amount of VP16 in the LDH hybrids at release time 0 and t, respectively, and $\mathrm{k}$ is the corresponding release rate constant. ${ }^{40}$

\section{In vitro cytotoxicity and antitumor effect of VPI6-LDH}

Human gastric epithelial cell line (GES-1) and human gastric cancer cell lines (MKN45 and SGC-7901) were used in this study. Cells were routinely cultured at $37^{\circ} \mathrm{C}$ in $5 \% \mathrm{CO}_{2}$ atmosphere in the flasks containing $10 \mathrm{~mL}$ of Dulbecco's modified Eagle medium supplemented with $10 \%$ fetal calf serum, $100 \mathrm{U} / \mathrm{mL}$ penicillin, and $100 \mu \mathrm{g} / \mathrm{mL}$ streptomycin. At $80 \%-90 \%$ confluence, cells were disassociated using trypsin-EDTA (Ethylene Diamine Tetraacetic Acid) and plated at a density of approximate $2 \times 10^{4}$ cells per well in a 96-well plate. The number of viable cells was determined by MTT assay with 3-(4,5-dimethylthiazol-2-yl)-2,5diphenyltetrazolium bromide. After incubation at $37^{\circ} \mathrm{C}$ in a $5 \% \mathrm{CO}_{2}$ humid atmosphere for 24 hours, triplicate wells were treated with VP16, VP16-LDH, and LDH of various concentrations $(5 \mu \mathrm{g} / \mathrm{mL}, 10 \mu \mathrm{g} / \mathrm{mL}, 20 \mu \mathrm{g} / \mathrm{mL}$, and $40 \mu \mathrm{g} /$ $\mathrm{mL}$ ), and incubation was continued as indicated above for 4 hours. For the LDH-treated wells, the amount of LDH was adjusted to be equal to that of VP16-LDH-treated wells. Subsequently, each well was incubated with $20 \mu \mathrm{L}(5 \mathrm{mg} / \mathrm{mL})$ of MTT dye solution for 4 hours at $37^{\circ} \mathrm{C}$. After removal of the 
MTT solution, cells were treated with $150 \mu \mathrm{L}$ of dimethyl sulfoxide, and the optical density absorbance at $490 \mathrm{~nm}$ was quantified using a microplate reader (BioTek Instruments Inc, Winooski, VT, USA ). Cell viability was calculated by means of the following formula:

$$
\text { Cell viability }(\%)=\frac{\mathrm{OD}_{490(\text { sample })}-\mathrm{OD}_{490(\text { blank })}}{\mathrm{OD}_{490(\text { control })}-\mathrm{OD}_{490(\text { blank })}} \times 100 \%
$$

\section{Results and discussion XRD analysis}

XRD patterns of LDH and the VP16-LDH nanohybrid are shown in Figure 2, and the basal spacing calculated from the XRD patterns is shown in Table 1. As shown in Figure 2, pristine LDH showed a typical XRD pattern for LDH-NO $\mathrm{N}_{3}$ with basal spacing of $0.84 \mathrm{~nm}$. Intercalation of drugs led to a significant increase in the interlayer space. As shown in Figure 2B, the reflection peaks in the pattern for VP16-LDH shift to lower angles and become weaker. This suggested that the successful intercalation of VP16 anions increased the basal spacing from $0.84-1.18 \mathrm{~nm}$. Assuming a thickness of $0.48 \mathrm{~nm}$ for the brucite-like layer of $\mathrm{LDH},{ }^{41}$ the gallery height in VP16-LDH became $0.70 \mathrm{~nm}$, which is shorter than the molecular length of VP16 ( $\approx 1.34 \mathrm{~nm})$. As shown in Figure 3, based on the calculated gallery height, it can be deduced that the VP16 molecules were arranged in a tilted longitudinal monolayer, with tilting angles of approximately $58^{\circ}$. As shown in Table 1 , the amount of VP16 intercalated into the LDH was calculated using a

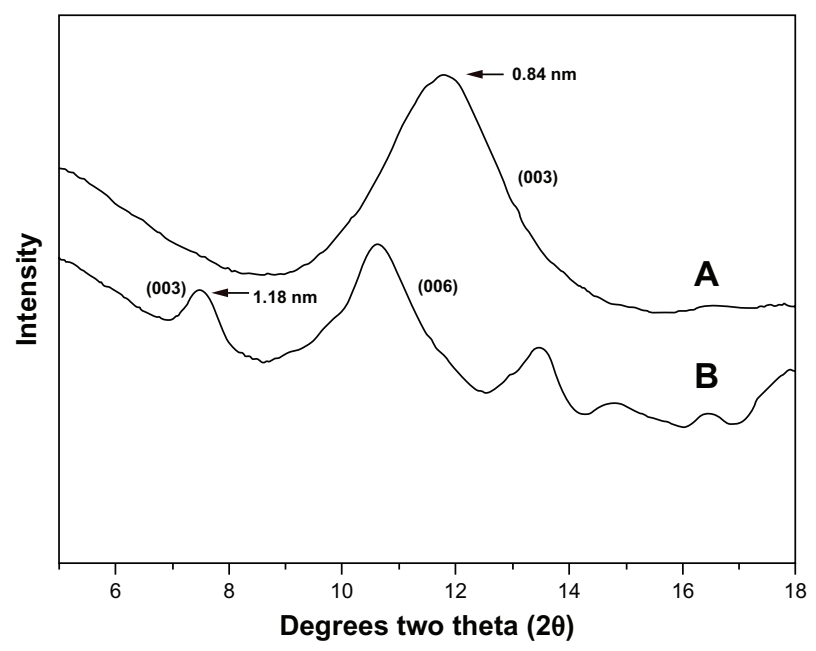

Figure 2 X-ray powder diffraction patterns for Mg/AI-LDH and VPI6-LDH. (A) X-ray powder diffraction pattern for Mg/Al-LDH. (B) X-ray powder diffraction pattern for VPI6-LDH.

Abbreviations: $\mathrm{Mg} / \mathrm{Al}-\mathrm{LDH}$, magnesium-aluminum layered double hydroxides; LDH, layered double hydroxide; VPI6, etoposide.
Table I The d-values of nanohybrid and VPI6 loading

\begin{tabular}{llllll}
\hline Nanohybrid & \multicolumn{2}{l}{ d-values, $\mathbf{n m}$} & \multicolumn{2}{l}{$\begin{array}{l}\text { Gallery } \\
\text { height, } \mathbf{n m}\end{array}$} & $\begin{array}{l}\text { VPI6 } \\
\text { loading, \% (w/w) }\end{array}$ \\
\cline { 2 - 5 } $\mathbf{d}_{003}$ & $\mathbf{d}_{006}$ & $\mathbf{d}_{009}$ & & \\
\hline LDH-NO $_{3}$ & 0.84 & 0.54 & 0.42 & 0.48 & - \\
VPI6-LDH & 1.18 & 0.83 & 0.66 & 0.70 & 21.94 \\
\hline
\end{tabular}

Abbreviations: d, distance of layer; VPI6, etoposide; LDH, layered double hydroxide.

UV-VIS spectrophotometer and its drug loading was about $21.94 \%(\mathrm{w} / \mathrm{w})$.

\section{Fourier transform infrared (FTIR) and thermal stability analysis}

The intercalation of VP16 into LDH interlayers was also suggested by infrared spectroscopy. As shown in Figure 4A, the pristine $\mathrm{LDH}-\mathrm{NO}_{3}$ spectrum contained some peaks that commonly appear in magnesium-aluminum layered double hydroxides spectra. ${ }^{18,42}$ The broad absorption band around $3400 \mathrm{~cm}^{-1}$ was due to the stretching of $\mathrm{O}-\mathrm{H}$ groups of both the hydroxide layer and interlayer water. The strong absorption band at $1384 \mathrm{~cm}^{-1}$ was due to stretching vibration of $\mathrm{NO}_{3}{ }^{-}$. In the low-frequency region, the bands at 809,601 , and $436 \mathrm{~cm}^{-1}$ were ascribed to the lattice vibration modes, specifically to $\mathrm{M}-\mathrm{O}$ and $\mathrm{O}-\mathrm{M}-\mathrm{O}$ vibrations. As shown in Figure 4B and C, in the infrared spectrum of VP16 and VP16$\mathrm{LDH}$, the characteristic peaks around the absorption bands at $1486 \mathrm{~cm}^{-1}$ were due to the stretching vibrations of $\mathrm{C}=\mathrm{C}$ in the backbone of the aromatic phenyl ring. Moreover, other VP16 absorption bands at 1249 and $1105 \mathrm{~cm}^{-1}$ observed in VP16-LDH were due to $\mathrm{C}-\mathrm{H}$ vibration. Anionic exchange reaction resulted in the $\mathrm{NO}_{3}^{-}$band at $1384 \mathrm{~cm}^{-1}$ becoming weaker, confirming that the interlayer $\mathrm{NO}_{3}^{-}$ions were partly

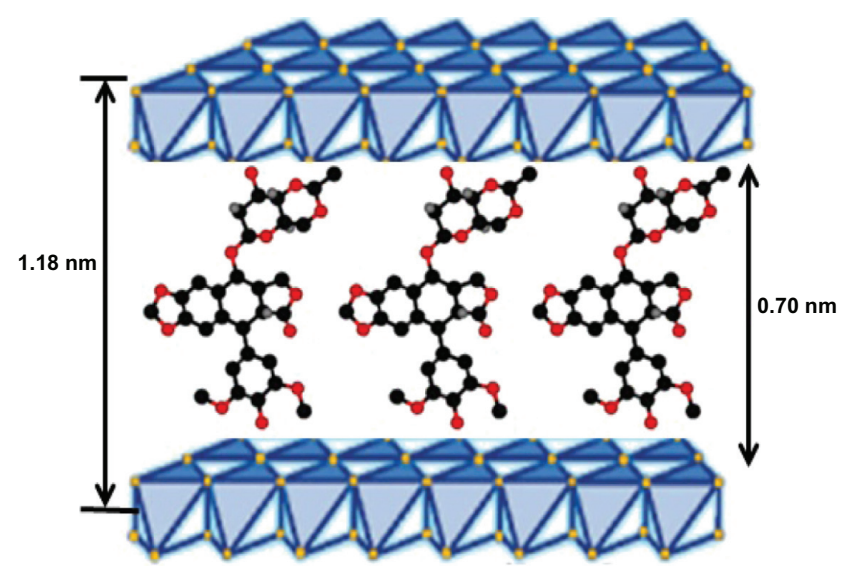

Figure 3 Schematic model of monolayer packing of VPI6 drug molecules in the LDH interlayer space.

Abbreviations: VPI6, etoposide; LDH, layered double hydroxide. 


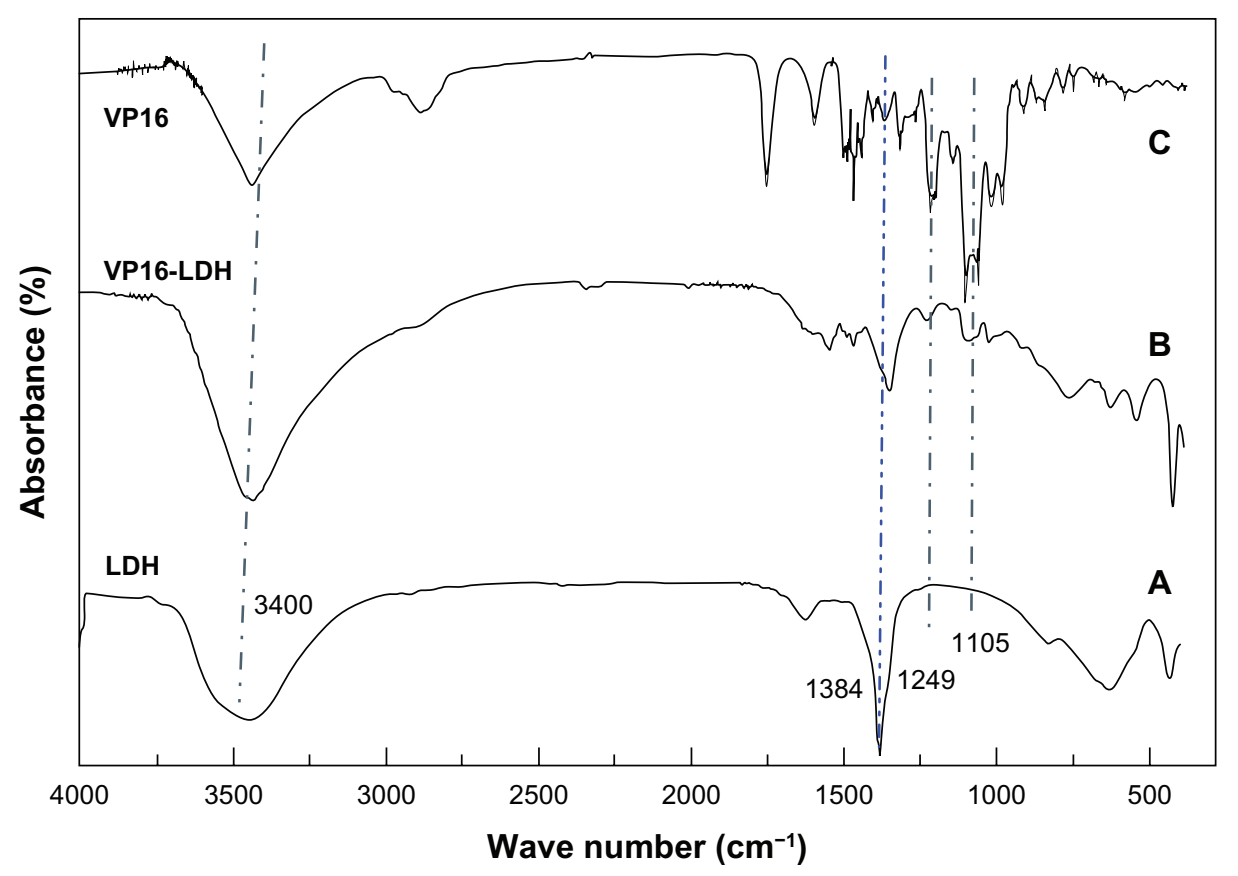

Figure 4 The FT-IR spectra for VPI6, VPI6-LDH, and Mg/AI-LDH. (A) FT-IR spectra for VPI6. (B) FT-IR spectra for VPI6-LDH. (C) FT-IR spectra for Mg/AI-LDH. Abbreviations: VPI6, etoposide; LDH, layered double hydroxide; Mg/AI-LDH, magnesium-aluminum layered double hydroxides; FT-IR, Fourier transform infrared.

replaced by VP16 molecules. Therefore, it was clear that VP16 successfully intercalated into LDH.

The TG/DTA curves of VP16-LDH nanohybrids are depicted in Figure 5. The sample shows two noticeable weight loss stages. The first stage occurred at approximately $100^{\circ} \mathrm{C}-200^{\circ} \mathrm{C}$ due to the removal of absorbed water molecules and interlayer crystal water, overlapping with trace dehydroxylation of the LDH layer. The following mass loss at around $300^{\circ} \mathrm{C}-400^{\circ} \mathrm{C}$ is attributed to dehydroxylation of the hydroxide layer and thermal degradation of intercalated VP16 molecules. The temperature was higher than the decomposition temperature of VP16, which demonstrated that the thermal stability of intercalated VP16 molecule was enhanced. Furthermore, the major weight loss of VP16-LDH in temperatures ranging from $300^{\circ} \mathrm{C}-400^{\circ} \mathrm{C}$ was approximately $24.01 \%$, which is similar to the loading amount of VP16 measured by UV-VIS spectroscopy. ${ }^{26,27}$

\section{Particle size distribution and TEM examination}

The particle size and distribution dynamics of VP16-LDH were investigated by photon correlation spectroscopy. The nanoparticles of LDH and VP16-LDH were narrowly distributed with a nominal hydrodynamic diameter of $57.4 \mathrm{~nm}$ (Figure 6A) and $62.5 \mathrm{~nm}$ (Figure 6C), respectively; the zeta potentials were $35.3 \mathrm{mV}$ (Figure 6B) and $20.5 \mathrm{mV}$ (Figure 6D), respectively.
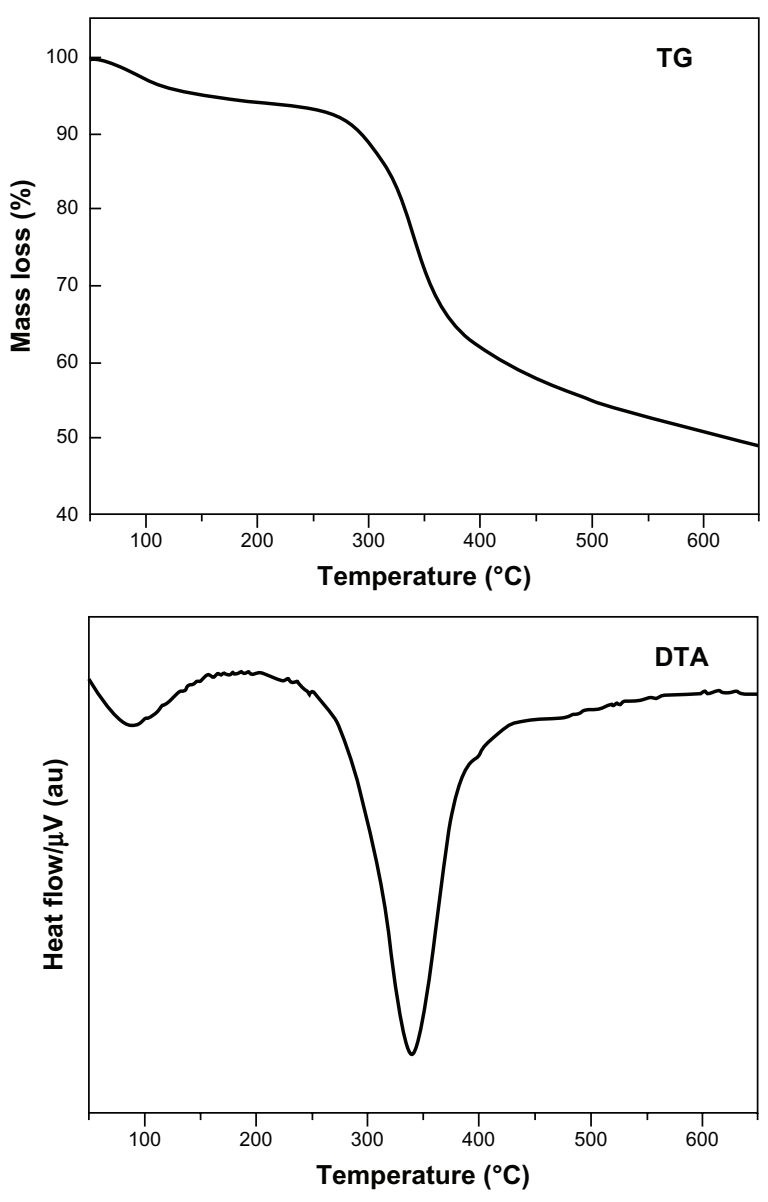

Figure 5 TG/DTA curves of VPI6-LDH.

Abbreviations: au, arbitrary unit; TG, thermogravimetry; DTA, differential thermal analysis; VPI6, etoposide; LDH, layered double hydroxide. 

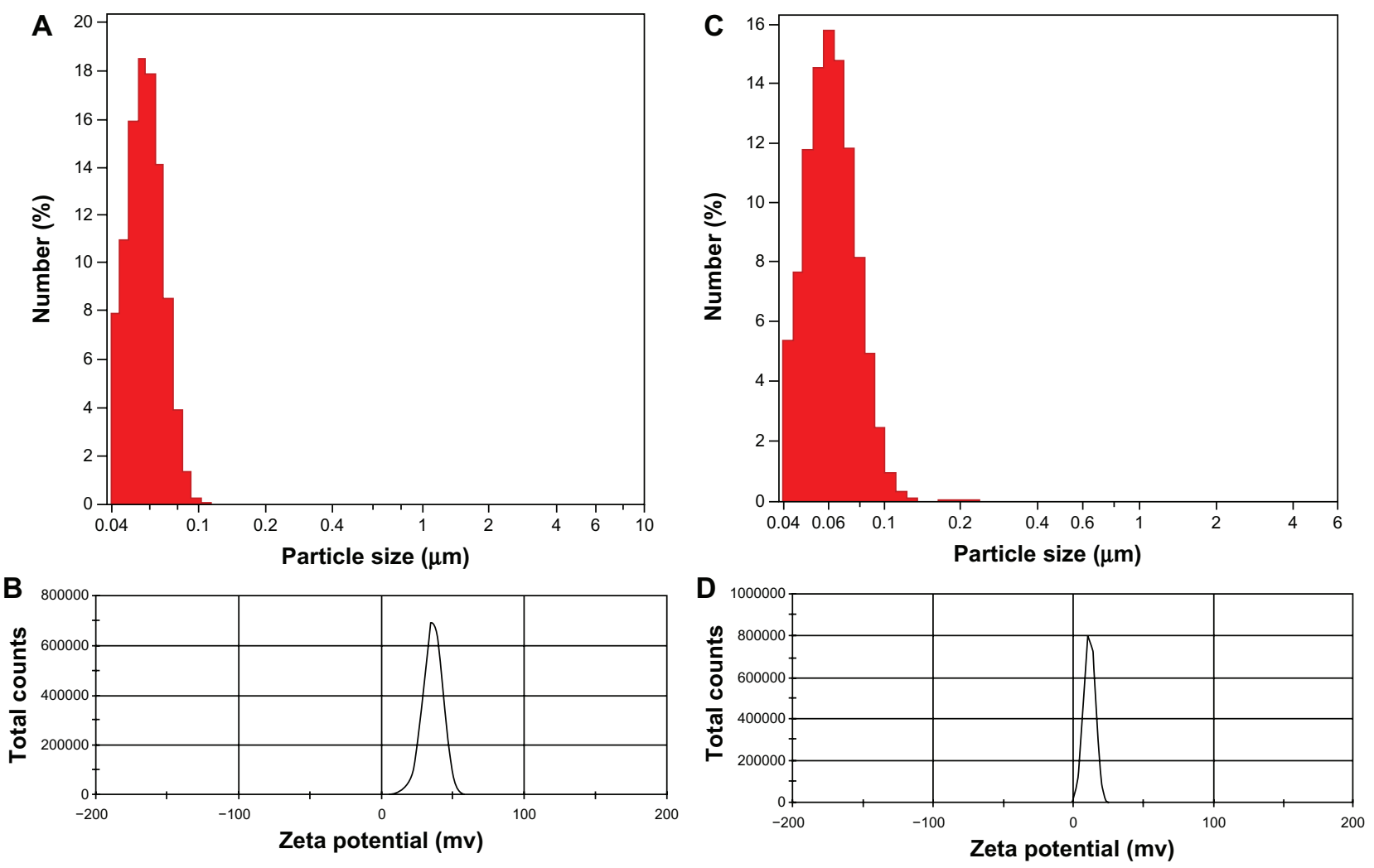

Figure 6 Particle size distribution and zeta potential distribution of LDH and VPI6-LDH nanoparticles. (A and B) Particle size distribution and zeta potential distribution of LDH and (C and D) VPI6-LDH nanoparticles.

Abbreviations: VPI6, etoposide; LDH, layered double hydroxide.

TEM samples were prepared by adding $300 \mathrm{~mL}$ of LDH slurry to $15 \mathrm{~mL}$ of deionized water followed by probe sonication of the solution for 2 minutes. A drop of the solution was then placed on a holey carbon copper grid and air dried. As shown in Figure 7, magnesium-aluminum layered double hydroxides were observed as compact, nonporous crystallites with a hexagonal platelike shape and a diameter of approximately $50 \mathrm{~nm}$. When the VP16 intercalated into the inorganic host, the shape of the nanohybrid changed from regular hexagon to ellipse,
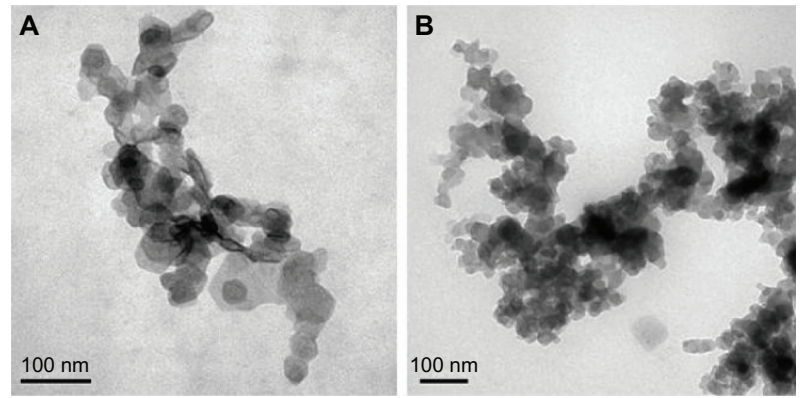

Figure 7 TEM images of nanohybrids. (A) Mg/Al-LDH crystals. (B) VPI6-LDH nanohybrid crystals.

Abbreviations: TEM, transmission electron microscope; Mg/AI-LDH, magnesiumaluminum layered double hydroxides; LDH, layered double hydroxide; VPI6, etoposide. and the crystal size increased, which was in accordance with the results of photon correlation spectroscopy.

\section{Buffer effect of VPI6-LDH}

Gastric fluids were mimicked to study the buffer effect of VP16-LDH nanohybrids by monitoring the changes in $\mathrm{pH}$ values with the addition of $1 \mathrm{M} \mathrm{HCl} .{ }^{43}$ Figure 8 depicts the

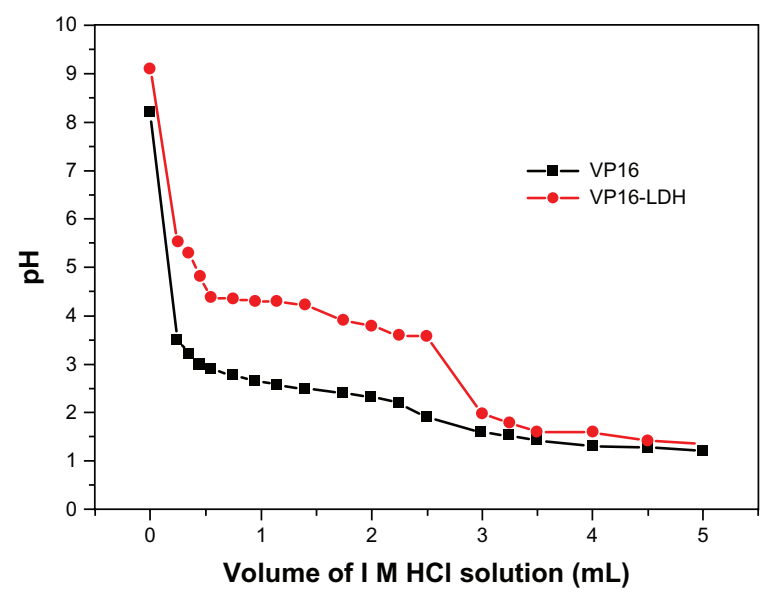

Figure 8 Titration curves of VPI6-LDH.

Note: $\mathrm{V}$ represents the added volume of I $\mathrm{mol} / \mathrm{L} \mathrm{HCl}$ aqueous solution. Abbreviations: VPI6, etoposide; LDH, layered double hydroxide. 
corresponding graphs of $\mathrm{pH}$ value versus the volume of aqueous $\mathrm{HCl}$ solution added to the nanohybrid suspensions. As shown in Figure 8, the $\mathrm{pH}$ response of VP16 did not support a buffering property when $\mathrm{pH}$ value changed. However, VP16LDH exhibited major buffering capacity when $\mathrm{pH}$ value was around 4. The neutralizing and buffering capabilities of VP16-LDH nanohybrids may come from the hydroxyl groups in its layers, and this function verifies LDH's effective role of antacid, which is also described in our previous study. ${ }^{26,27,44}$ A three-phase release process can be observed. At the first stage with additive of $\mathrm{HCl}$, the exfoliation of $\mathrm{LDH}$ particles was made by $\mathrm{HCl}$ to induce the integrity of the coating layer destroyed, which resulted in sharp decrement of solution $\mathrm{pH}$ from about 9.5-5.5. At the second stage, the $\mathrm{pH}$ of medium solution kept around 4, which was dependent on the neutralizing and buffering capabilities of VP16-LDH. At the last stage, the $\mathrm{pH}$ of medium solution was cut down and got to be 1 as the $\mathrm{LDH}$ nanoparticles were consumed by $\mathrm{HCl}$. It may serve as an indicator that the LDH has begun dissolving; releasing VP16 through the removal of inorganic hosts under acidic conditions. ${ }^{45}$ Thus, LDH may be an ideal antacid to prompt available VP16 diffusion in simulated gastric fluid.

\section{In vitro drug release of VPI6-LDH}

The release properties of the VP16 from VP16-LDH were investigated by adding the intercalated compound to a sample of simulated gastrointestinal ( $\mathrm{pH} 4.6)$ and blood fluids ( $\mathrm{pH}$ 7.4). Figure 9 shows the release profiles of VP16-LDH nanohybrids and physically mixed powder (VP16 and LDH) in solutions at $\mathrm{pH} 4.6$ and 7.4. VP16 released from VP16-LDH nanohybrids at $\mathrm{pH} 4.6$ and 7.4 showed a burst release during the first 20 minutes, which can be attributed to the release of the VP16 that adsorbed onto the surface of LDH particles. Subsequently, a slower release behavior was observed, which may be due to an ion-exchange process between the intercalated anions in the interlayer and phosphate anions in the buffer. ${ }^{46}$ At $\mathrm{pH} 7.4$, the release of VP16-LDH was persistent and gradual, with released percentages of $51 \%, 74 \%$, and $79 \%$ after 20, 150, and 390 minutes, respectively. As for the physical mixtures of VP16 and LDH, the release rate reached $85 \%$ immediately after 20 minutes, due to weak electrostatic interaction between VP16 molecules and the LDH surface. Thereafter, a slow decline of VP16 was observed with about 80\% VP16 left in solution after 390 minutes, which may be attributed to the intercalation of VP16 into LDH. Such intercalation has been previously reported while observing the release of other drugs from a physical mixture. ${ }^{32}$ Therefore, it can be concluded that VP16-LDH shows an obvious sustained release profile. This nanomaterial could help increase the practical delivery of VP16.

Four types of dissolution-diffusion kinetic models (zero-order, first-order, parabolic diffusion, and modified

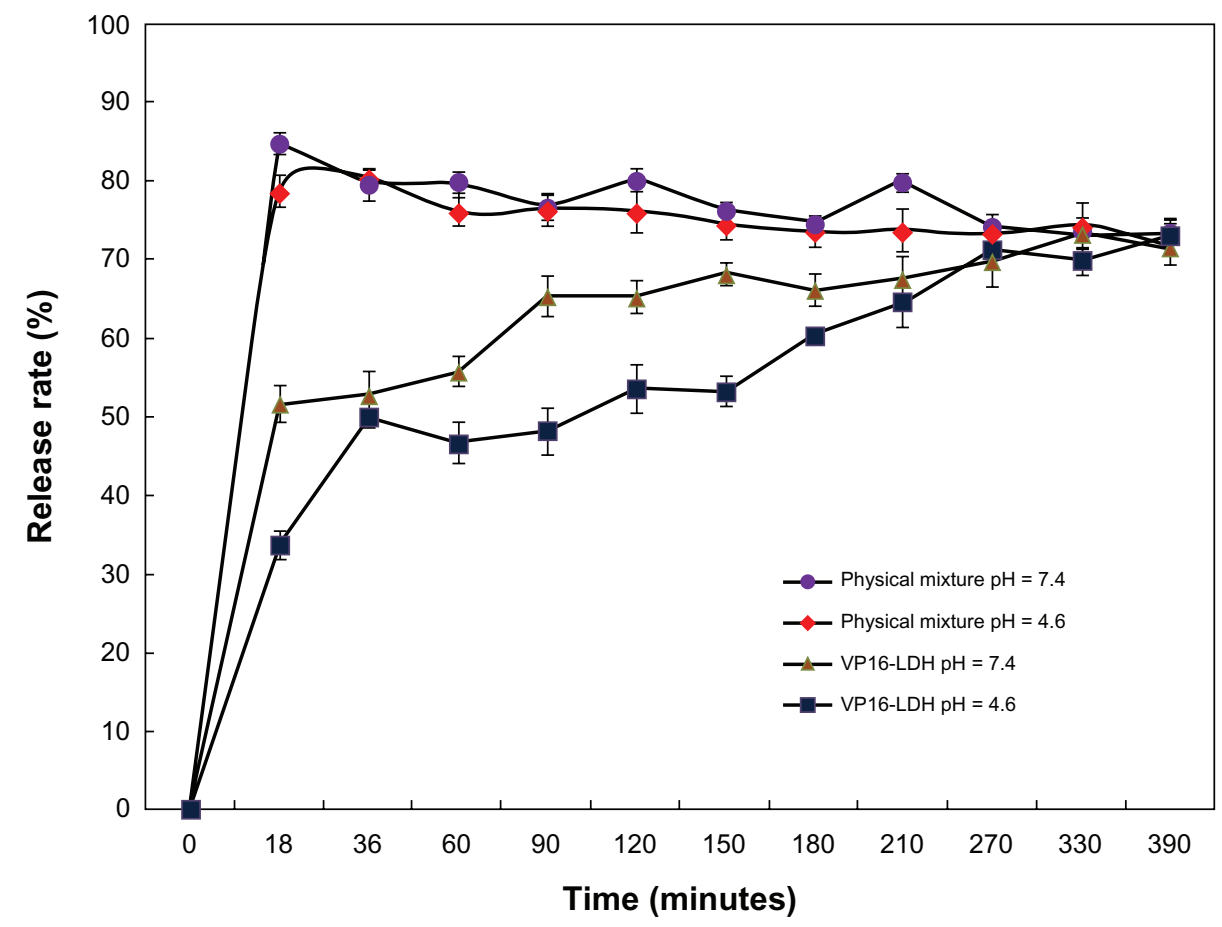

Figure 9 The in vitro release profiles of VPI6 from VPI6-LDH and physical mixture in buffer solutions at different $\mathrm{pH}$ values. Abbreviations: VPI6, etoposide; LDH, layered double hydroxide. 
Table 2 Rate constants and correlation coefficients of the dissolution-diffusion kinetic models applied to VPI 6 release from VPI6-LDH

\begin{tabular}{llll}
\hline $\begin{array}{l}\text { Kinetic } \\
\text { model }\end{array}$ & Kinetic equation & $\mathbf{R}^{2}(\mathbf{p H}=\mathbf{7 . 4})$ & $\mathbf{R}^{\mathbf{2}}(\mathbf{p H}=\mathbf{4 . 6})$ \\
\hline Zero-order & $\mathrm{M}_{\mathrm{t}}-\mathrm{M}_{\mathrm{o}}=\mathrm{kt}+\mathrm{a}$ & 0.4225 & 0.6624 \\
First-order & $\mathrm{Ln}\left(\mathrm{M}_{\mathrm{t}} / \mathrm{M}_{\mathrm{o}}\right)=-\mathrm{kt}+\mathrm{a}$ & $0.593 \mathrm{I}$ & 0.8345 \\
Parabolic & $\left.\left(\mathrm{I}-\mathrm{M}_{\mathrm{t}} / \mathrm{M}_{0}\right) / \mathrm{t}\right)=$ & 0.9697 & 0.9783 \\
$\begin{array}{l}\text { diffusion } \\
\text { model }\end{array}$ & $\mathrm{kt}^{-0.5}+\mathrm{a}$ & \\
$\begin{array}{l}\text { Modified } \\
\text { Freundlich }\end{array}$ & $\mathrm{I}-\mathrm{M}_{\mathrm{t}} / \mathrm{M}_{0}=\mathrm{kt}^{\mathrm{a}}$ & 0.9230 & 0.8977 \\
model & & & \\
\hline
\end{tabular}

Abbreviations: VPI6, etoposide; LDH, layered double hydroxide.

Freundlich model) were used in an attempt to explain the mechanism of release. The corresponding linear correlation coefficients $\left(\mathrm{R}^{2}\right)$ were calculated (Table 2). At $\mathrm{pH} 7.4$, the zero- and first-order models were not suitable to explain the whole release pattern of VP16-LDH, as evidenced by their
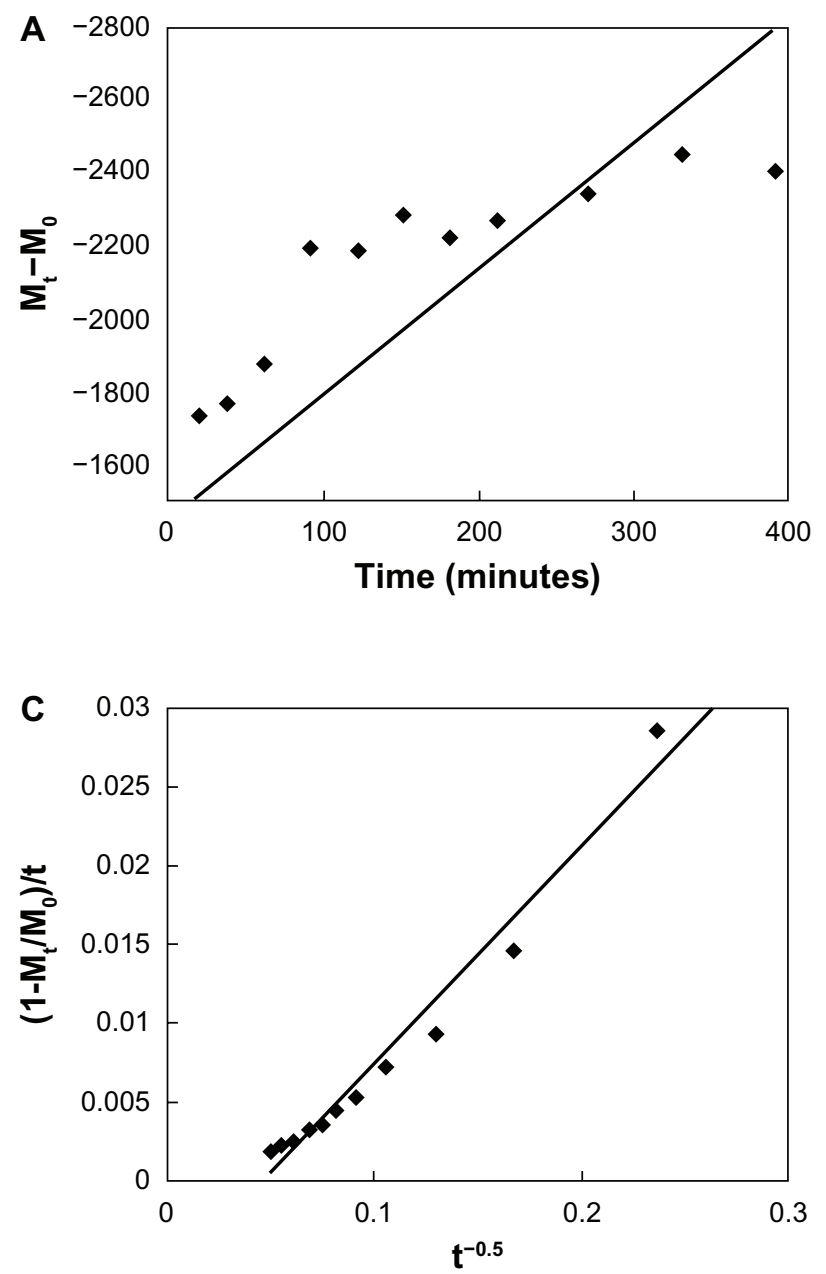

small linear correlation coefficients with $\mathrm{R}^{2}=0.4225$ and 0.5931 (Figure 10). The release of VP16-LDH followed the other two models much better, with $\mathrm{R}^{2}=0.9697$ and 0.9230 for the parabolic diffusion and modified Freundlich models, respectively. The parabolic diffusion model describes intraparticle diffusion or surface diffusion, whereas the modified Freundlich model describes heterogeneous diffusion from flat surfaces via ion exchange. Thus, the drug release may be a coeffect, and a possible mechanism for VP16 release involves both intraparticle diffusion and surface diffusion, with either one being the main contributor. ${ }^{44}$ At $\mathrm{pH} 4.6$ (Figure 11), the zero- and first-order models were also not suitable for the release pattern with the $\mathrm{R}^{2}=0.6624$ and 0.8345; however, the parabolic diffusion model was the best fit model for the release of VP16 $\left(R^{2}=0.98\right)$. This suggests that the release from VP16-LDH is controlled by the diffusion of VP16 anions from inside to the surface of the LDH particles.
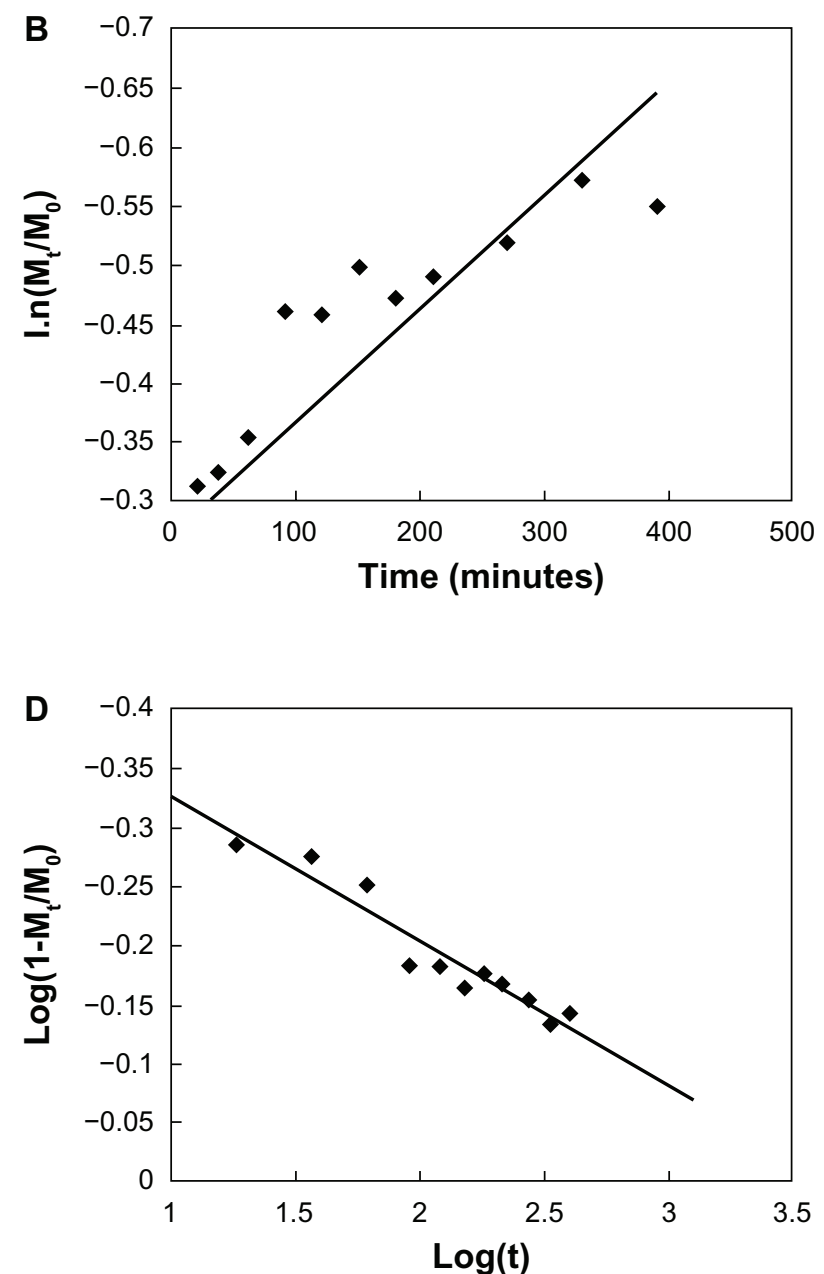

Figure 10 Fitting the VPI6-LDH release data at pH 7.4 to different kinetic equations. (A) Zero-order, (B) first-order, (C) parabolic diffusion model, and (D) modified Freundlich model.

Abbreviations: VPI6, etoposide; LDH, layered double hydroxide; t, time. 

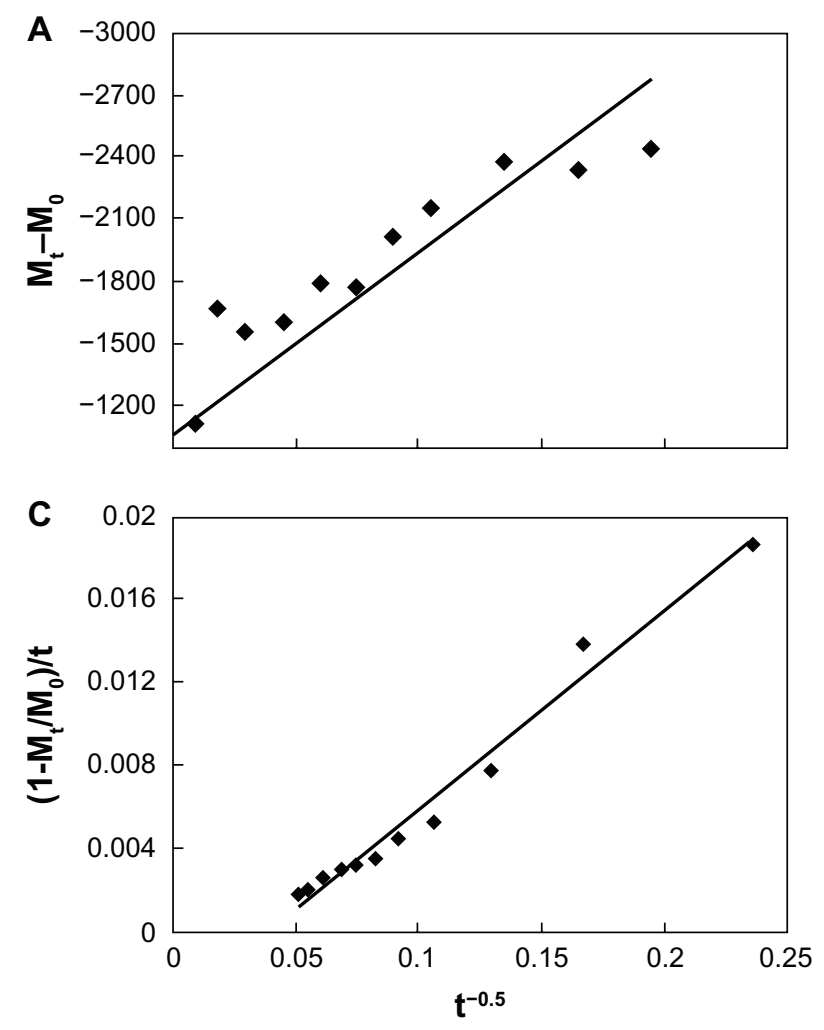

Figure II Fitting the VPI6-LDH release data at $\mathrm{pH} 4.6$ to different kinetic equations. Freundlich model.

Abbreviations: VPI6, etoposide; LDH, layered double hydroxide; t, time.

\section{In vitro cytotoxicity and antitumor effect of VPI6-LDH}

Figure 12A shows the effect of VP16, LDH, and VP16LDH on the proliferation of GES-1 cells at various VP16 concentrations. The cytotoxicity of VP16 and VP16-LDH to GES-1 cells increased with increasing dose of VP16, whereas pristine LDH had no significant cytotoxic effect. VP16-LDH has no obvious toxicity to GES-1 cells compared with free VP16 of the same concentration. Thus, LDH, as carriers of VP16, can effectively reduce the cytotoxicity of VP16 to normal cells.

As shown in Figure 12B and C, VP16 and VP16-LDH suppressed the proliferation of tumor cells MKN45 and SGC-7901, whereas LDH by itself exerted no significant effect. Moreover, VP16-LDH had higher tumor suppression efficiency than VP16 alone at various concentrations. These results indicate that VP16-LDH may be more effective in cancer treatment than VP16 alone. This may be because VP16 in the hybrid system can reach tumor cell membranes before decomposing, because the VP16 molecules are stabilized when they are entrapped in LDH. Additionally, Choy et $a{ }^{47}$ reported that the use of LDH nanoparticles as delivery vectors can improve the cellular uptake of biomolecules.
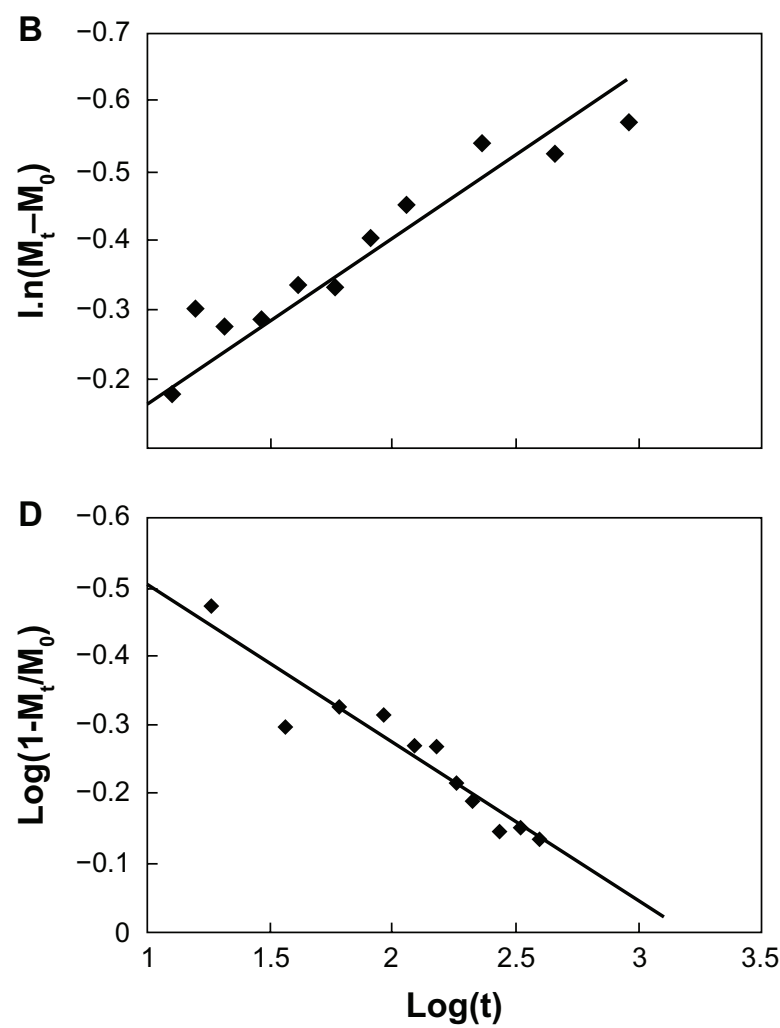

(A) Zero-order, (B) first-order, (C) parabolic diffusion model, and (D) modified 

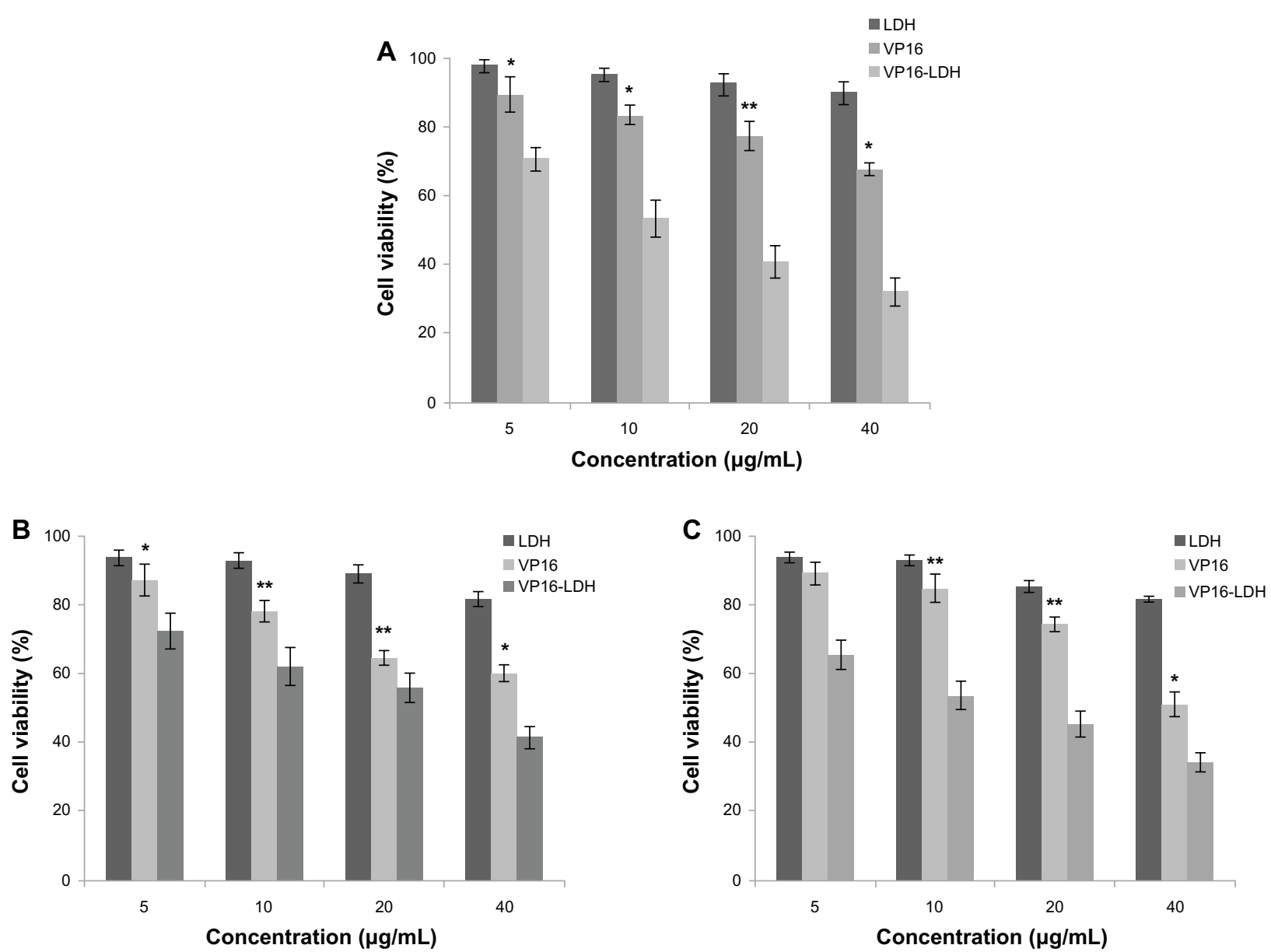

Figure 12 The effect of LDH, VPI6, and VPI6-LDH of different VPI6 concentrations on GES-I cells and MKN45 and SGC-790I tumor cells after 48 hours of incubation. (A) Cytotoxicity of LDH, VPI6, and VPI6-LDH of different VPI6 concentrations to GES-I cells after 48 hours. The effect of LDH, VPI6, and VPI6-LDH of different VPI6 concentrations on the growth of MKN45 (B) and SGC-790I (C) tumor cells after 48 hours.

Notes: Results represent the means of three independent experiments, and error bars represent the standard error of the mean. $\mathrm{N}=3 ; * \mathrm{P}<0.05 ; * * P<0.00 \mathrm{I}$.

Abbreviations: LDH, layered double hydroxide; VPI6, etoposide.

\section{Conclusion}

We successfully synthesized and characterized druginorganic nanohybrids, specifically constructs consisting of LDHs intercalated with VP16. The prepared nanoparticles contained an average diameter of $62.5 \mathrm{~nm}$ with a zeta potential of $20.5 \mathrm{mV}$. Evaluation of the buffering effect of VP16-LDH indicated that VP16-LDH possessed a good buffer effect in low $\mathrm{pH}$ media. The loading amount of intercalated VP16 was $21.94 \%$ and showed a profile of sustained release making a promising candidate for controlled drug release applications. The cytotoxicity and antitumor tests showed that VP16-LDH nanoparticles exhibited low toxicity to normal GES-1 cells and better antitumor efficacy on MKN45 and SGC-7901 cells. In summary, LDH may be an excellent inorganic carrier of VP16, and VP16-LDH shows great potential as an antitumor therapy. The promising results encourage us to perform further in vivo delivery in an animal model in the future.

\section{Acknowledgments}

This work was financially supported by the National Natural Science Foundation of China (Grants 31100855 and 31140038), a Special Financial Grant from the China Postdoctoral Science Foundation (Grant 2012T50440), the Program for Young Excellent Talents in Tongji University (Grant 2000219054), and the Science and Technology Commission of Shanghai Municipality (Grant 11411951500).

\section{Disclosure}

The authors report no conflicts of interest in this work.

\section{References}

1. Drewinko B, Barlogie B. Survival and cycle-progression delay of human lymphoma cells in vitro exposed to VP-16-213. Cancer Treat Rep. 1976; 60(9):1295-1306.

2. Hainsworth JD, Greco FA. Etoposide: twenty years later. Ann Oncol. 1995;6(4):325-341.

3. Slevin ML. Low-dose oral etoposide: a new role for an old drug? J Clin Oncol. 1990;8(10):1607-1609. 
4. Lowis SP, Newell DR. Etoposide for the treatment of paediatric tumours: what is the best way to give it? Eur J Cancer. 1996;32A(13): 2291-2297.

5. You B, Tranchand B, Girard P, et al. Etoposide pharmacokinetics and survival in patients with small cell lung cancer: a multicentre study. Lung Cancer. 2008;62(2):261-272.

6. Van Maanen JM, Retèl J, de Vries J, Pinedo HM. Mechanism of action of antitumor drug etoposide: a review. J Natl Cancer Inst. 1988;80(19): 1526-1533.

7. Shah JC, Chen JR, Chow D. Preformulation study of etoposide: identification of physicochemical characteristics responsible for the low and erratic oral bioavailability of etoposide. Pharm Res. 1989;6(5): 408-412.

8. Hainsworth JD, Williams SD, Einhorn LH, Birch R, Greco FA. Successful treatment of resistant germinal neoplasms with VP-16 and cisplatin: results of a Southeastern Cancer Study Group trial. J Clin Oncol. 1985;3(5):666-671.

9. Seida Y, Nakano Y. Removal of phosphate by layered double hydroxides containing iron. Water Res. 2002;36(5):1306-1312.

10. Kwon SJ, Choy JH. A novel hybrid of Bi-based high-Tc superconductor and molecular complex. Inorg Chem. 2003;42(25):8134-8136.

11. Xu ZP, Lu GQ. Layered double hydroxide nanomaterials as potential cellular drug delivery agents. Pure Appl Chem. 2006;78(9):1771-1779.

12. Xu ZP, Zeng QH, Lu GQ, Yu AB. Inorganic nanoparticles as carriers for efficient cellular delivery. Chem Eng Sci. 2006;61(3):1027-1040.

13. Choy JH, Kim YI, Kim BW, Campet G, Portier J, Huong PV. Grafting mechanism of electrochromic PAA-WO ${ }_{3}$ composite film. J Solid State Chem. 1999;142(2):368-373.

14. Choy JH, Yoon JB, Park JH. In situ XAFS study at the Zr K-edge for SiO2/ZrO2 nano-sol. J Synchrotron Radiat. 2001;8(Pt 2):782-784.

15. Kwak SY, Kriven WM, Wallig MA, Choy JH. Inorganic delivery vector for intravenous injection. Biomaterials. 2004;25(28):5995-6001.

16. Hofer C, Teichert C, Wächter M, Bobek T, Lyutovich K, Kasper E. Nanostructure formation on ion-eroded SiGe film surfaces. Superlattices and Microstructures. 2004;36(1-3):281-291.

17. Li A, Qin LL, Wang SL, et al. The use of layered double hydroxides as DNA vaccine delivery vector for enhancement of anti-melanoma immune response. Biomaterials. 2011;32(2):469-477.

18. Aisawa S, Takahashi S, Ogasawara W, Umetsu Y, Narita E. Direct intercalation of amino acids into layered double hydroxides by coprecipitation. J Solid State Chem. 2001;162(1):52-62.

19. Zhang H, Qi R, Evans DG, Duan X. Synthesis and characterization of a novel nano-scale magnetic solid base catalyst involving a layered double hydroxide supported on a ferrite core. J Solid State Chem. 2004;177(3):772-780.

20. Hibino T, Nishiyama T. Role of TGF-beta2 in the human hair cycle. J Dermatol Sci. 2004;35(1):9-18.

21. Wong KK, Colfen H, Whilton NT, Douglas T, Mann S. Synthesis and characterization of hydrophobic ferritin proteins. J Inorg Biochem. 1999;76(3-4):187-195.

22. Nakayama H, Hayashi A, Eguchi T, Nakamura N, Tsuhako M. Adsorption of formaldehyde by polyamine-intercalated $\alpha$-zirconium phosphate. Solid State Sciences. 2002;4(8):1067-1070.

23. Wang G, Feng L, Luck RL, Evans DG, Wang Z, Duan X. Sol-gel synthesis, characterization and catalytic property of silicas modified with oxomolybdenum complexes. J Mol Catal A Chem. 2005;241(1-2):8-14.

24. Zhang H, Zou K, Sun H, Duan X. A magnetic organic-inorganic composite: synthesis and characterization of magnetic 5-aminosalicylic acid intercalated layered double hydroxides. J Solid State Chem 2005;178(11):3485-3493.

25. Zhang H, Zou K, Guo S, Duan X. Nanostructural drug-inorganic clay composites: structure, thermal property and in vitro release of captoprilintercalated Mg-Al-layered double hydroxides. J Solid State Chem. 2006;179(6):1792-1801

26. Xiao R, Wang WR, Pan L, et al. A sustained folic acid release system based on ternary magnesium/zinc/aluminum layered double hydroxides. J Mater Sci. 2011;46(8):2635-2643.
27. Qin LL, Wang SL, Zhang R, Zhu RG, Sun XY, Yao S. Two different approaches to synthesizing Mg-Al-layered double hydroxides as folic acid carriers. J Phys Chem Solids. 2008;69(11):2779-2784.

28. Qin L, Xue M, Wang W, et al. The in vitro and in vivo anti-tumor effect of layered double hydroxides nanoparticles as delivery for podophyllotoxin. Int J Pharm. 2010;388(1-2):223-230.

29. Li B, He J, Evans DG, Duan X. Enteric-coated layered double hydroxides as a controlled release drug delivery system. Int J Pharm. 2004; 287(1-2):89-95.

30. Choi SJ, Choy JH. Layered double hydroxide nanoparticles as targetspecific delivery carriers: uptake mechanism and toxicity. Nanomedicine (Lond). 2011;6(5):803-814.

31. Ambrogi V, Famiani F, Perioli L, Marmottini, Di Cunzolo I, Rossi C. Effect of MCM-41 on the dissolution rate of the poorly soluble plant growth regulator, the indole-3-butyric acid. Microporous and Mesoporous Materials. 2006;96(1-3):177-183.

32. Gu Z, Thomas AC, Xu ZP, Campbell JH, Lu GQ. In vitro sustained release of LMWH from MgAl-layered double hydroxide nanohybrids. Chem Mater. 2008;20(11):3715-3722.

33. Tyner KM, Schiffman SR, Giannelis EP. Nanobiohybrids as delivery vehicles for camptothecin. J Control Release. 2004;95(3):501-514.

34. Xue YH, Zhang R, Sun XY, Wang SL. The construction and characterization of layered double hydroxides as delivery vehicles for podophyllotoxins. J Mater Sci Mater Med. 2008;19(3): 1197-1202.

35. Xu ZP, Walker TL, Liu KL, Cooper HM, Lu GQ, Bartlett PF. Layered double hydroxide nanoparticles as cellular delivery vectors of supercoiled plasmid DNA. Int J Nanomedicine. 2007;2(2):163-174.

36. Li ZH. Sorption kinetics of hexadecyltrimethylammonium on natural clinoptilolite. Langmuir. 1999;15(19):6438-6445.

37. Yang JH, Han YS, Park M, et al. New inorganic-based drug delivery system of indole-3-acetic acid-layered metal hydroxide nanohybrids with controlled release rate. Chem Mater. 2007;19(10): 2679-2685.

38. Demirbas E, Kobya M, Senturk E, Ozkan T. Adsorption kinetics for the removal of $\mathrm{Cr}$ (VI) from aqueous solutions on the activated carbons prepared from agricultural wastes. Water South Africa. 2004;30:533-539.

39. Kodama T, Harada Y, Ueda M, Shimizu KI, Shuto K, Komarneni S. Selective exchange and fixation of strontium ions with ultrafine Na-4mica. Langmuir. 2001;17(16):4881-4886.

40. Sparks DL. Kinetics of Soil Chemical Processes. San Diego, CA: Harcourt Brace Jovanovich Publishers; 1989.

41. Choy JH, Jung JS, Oh JM, et al. Layered double hydroxide as an efficient drug reservoir for folate derivatives. Biomaterials. 2004;25(15): 3059-3064.

42. Kloprogge JT, Wharton D, Hickey L, Frost RL. Infrared and Roman study of interlayer anions $\mathrm{CO}_{3}{ }^{2-}, \mathrm{NO}_{3}{ }^{-}, \mathrm{SO}_{4}{ }^{2-}$ and $\mathrm{ClO}_{4}{ }^{-}$in $\mathrm{Mg} / \mathrm{Al}-$ hydrotalcite. American Mineralogist. 2000;87:623-629.

43. Tronto J, Crepaldi EL, Pavan PC, De Paula CC, Valim JB. Organic anions of pharmaceutical interest intercalated in magnesium aluminum LDHs by two different methods. Molecular Crystals Liquid Crystals. 2001;356(1):227-237.

44. Qian WY, Sun DM, Zhu RR, Du XL, Liu H, Wang SL. pH-sensitive strontium carbonate nanoparticles as new anticancer vehicles for controlled etoposide release. Int J Nanomedicine. 2012;7: 5781-5792.

45. bin Hussein MZ, Zainal Z, Yahaya AH, Foo DW. Controlled release of a plant growth regulator, alpha-naphthaleneacetate from the lamella of Zn-Al-layered double hydroxide nanocomposite. J Control Release. 2002;82(2-3):417-427.

46. Pan DK, Zhang H, Zhang T, Duan X. A novel organic-inorganic microhybrids containing anticancer agent doxifluridine and layered double hydroxides: Structure and controlled release properties. Chem Eng Sci. 2010;65(12):3762-3771.

47. Choy JH, Kwak SY, Park JS, Jeong YJ. Cellular uptake behavior of [ $\gamma$-32P] labeled ATP-LDH nanohybrids. J Mater Chem. 2001;11(6): 1671-1674. 
48. Oh JM, Choi SJ, Lee GE, Kim JE, Choy JH. Inorganic metal hydroxide nanoparticles for targeted cellular uptake through clathrin-mediated endocytosis. Chem Asian J. 2009;4(1):67-73.

49. Peer D, Karp JM, Hong S, Farokhzad OC, Margalit R, Langer R. Nanocarriers as an emerging platform for cancer therapy. Nat Nanotechnol. 2007;2(12):751-760.

50. Maeda $H$. The enhanced permeability and retention (EPR) effect in tumor vasculature: the key role of tumor-selective macromolecular drug targeting. Adv Enzyme Regul. 2001;41:189-207.
51. Fahmy TM, Fong PM, Goyal A, Saltzman WM. Targeted nanoparticles for drug delivery. Materials Today. 2005;8(8 Suppl 1):18-26.

52. Yuan H, Miao J, Du YZ, You J, Hu FQ, Zeng S. Cellular uptake of solid lipid nanoparticles and cytotoxicity of encapsulated paclitaxel in A549 cancer cells. Int J Pharm. 2008;348(1-2):137-145.

\section{Publish your work in this journal}

The International Journal of Nanomedicine is an international, peerreviewed journal focusing on the application of nanotechnology in diagnostics, therapeutics, and drug delivery systems throughout the biomedical field. This journal is indexed on PubMed Central, MedLine, CAS, SciSearch ${ }^{\circledR}$, Current Contents ${ }^{\circledR} /$ Clinical Medicine,
Journal Citation Reports/Science Edition, EMBase, Scopus and the Elsevier Bibliographic databases. The manuscript management system is completely online and includes a very quick and fair peer-review system, which is all easy to use. Visit http://www.dovepress.com/ testimonials.php to read real quotes from published authors. 